\title{
The Millennial's Investment Decisions: Implications of Financial Literacy, Motivation, and Digitalization
}

\author{
Vidya Purnamasari ${ }^{1}$, Santi Merlinda ${ }^{2}$, Bagus Shandy Narmaditya ${ }^{3}$, M. Rudi Irwansyah ${ }^{4}$
}

1,2,3Faculty of Economics, Universitas Negeri Malang, Indonesia

${ }^{4}$ Faculty of Education, Universitas Pendidikan Ganesha, Indonesia

\author{
A R T I C L E I N F O \\ Article history: \\ Received September, 11 \\ 2021 \\ Received in revised form \\ November, 222021 \\ Accepted November, 26 \\ 2021 \\ Available online December, \\ 252021

\section{Kata Kunci:} \\ Digitalisasi, keputusan \\ investasi, literasi keuangan, \\ motivasi. \\ Keywords: \\ Digitalization, financial \\ literacy, investment \\ decision, motivation.
}

\begin{abstract}
A B S T R A K
Investasi sebagai sarana untuk mengembangkan aset tidak lagi merupakan kegiatan mewah yang diperuntukkan bagi segelintir orang. Saat ini, seiring kemajuan teknologi keuangan, setiap orang memiliki akses yang sama terhadap informasi investasi. Perubahan ini menghasilkan perspektif baru di mana investasi tidak terbatas pada orang kaya, mengarahkan semua orang, bahkan milenial dengan anggaran terbatas untuk menjadi investor. Tujuan dari penelitian ini adalah untuk mengetahui variabel-variabel yang mempengaruhi keputusan berinvestasi pada usia dini, di kalangan milenial. Penelitian ini mengadopsi model regresi persamaan tunggal untuk menguji variabel dependen pada beberapa variabel penjelas dan memperkirakan nilai mean atau rata-rata. Pengumpulan data dilakukan dengan menggunakan kuesioner kepada 140 responden. Tiga variabel berbeda yang digunakan sebagai variabel independen adalah literasi keuangan, motivasi, dan digitalisasi platform investasi. Temuan menunjukkan bahwa literasi dan motivasi keuangan secara substansial mempengaruhi keputusan investasi generasi milenial, sementara digitalisasi tidak menunjukkan korelasi dengan keputusan investasi generasi Milenial.
\end{abstract}

\section{A B S T R A C T}

Investment as a means of developing assets is no longer a luxury activity reserved for a select few. Nowadays, as financial technology advances, everyone has equal access to investment information. This change generates new perspectives in which investing is not restricted to the wealthy, leading everyone, even on-budget millennials to be investors. The purpose of this research is to determine the variables affecting investing decisions at an early age, especially among millennials. This research adopted singleequation regression models to examine the dependent variable on several explanatory variables and estimate mean or average value. The data was generated using a questionnaire to 140 respondents. Three distinct variables utilized as independent variables are financial literacy, motivation, and the digitization of investing platforms. The findings indicate that financial literacy and motivation substantially affect millennials' investment decisions, while digitization presents no correlation to the Millennials' investment decisions.

\footnotetext{
* Corresponding author.

E-mail : vidya.purnamasari.fe@um.ac.id (Vidya Purnamasari)
} 


\section{Introduction}

Financial technology (fintech), as a breakthrough in the financial services industry, has brought many changes in human life. Nowadays, most economic activities involve the use of technology in every transaction. Furthermore, the use of fintech in the financial sector has proven to increase cost-effectiveness in banking and improve the performance of banking technology (Lee et al., 2021). From a different perspective, (Bollaert et al., 2021) reveal that fintech will increase public access to finance, increase investment opportunities and attract new investors. Along with technology development, fintech is becoming more diverse and applied to various fields. Not only improve banking services through mobile banking, but fintech has also penetrated the field of digital trade or e-commerce and the investment and financing sector. In Indonesia, the two e-commerce sites with the highest monthly website visitors are Tokopedia and Shopee, with monthly visitors reaching 137 million (Databoks, 2021). For the investment and financing sector, there is 125 fintech peer to peer lending providers that have been registered and can use legally by the public (OJK, 2021).

The ease of accessing fintech undoubtedly becomes one of the dominant factors supporting the increase of fintech users. In May 2020, fintech lending in Indonesia reached 13.86 trillion loan funds collected from 8.7 million entities. This value increased about $8 \%$ every month, where the total value of loan funds was only around 9.11 trillion from 6.5 million entities in early 2021 (OJK, 2021). The data reflects that community enthusiasm to use fintech in their daily activities has increased from time to time. The trend of fintech is exciting to explore briefly, especially from the millennial perspective, who grew up when technology was developing rapidly and showing its sophistication (Rosdiana, 2020). Through this condition, millennials benefit from adaptability to ease of implementing technology in daily activities. Based on the data in Figure 1, until May 2021, 65\% of the number of active loan recipient accounts (entities) in fintech lending are dominated by users aged 19 to 34 years $(\mathrm{OJK}, 2021)$. The current entity's monthly increase shows that millennials dominate the use of fintech lending in Indonesia. This value will undoubtedly be even more remarkable in the fintech total using in all sectors.

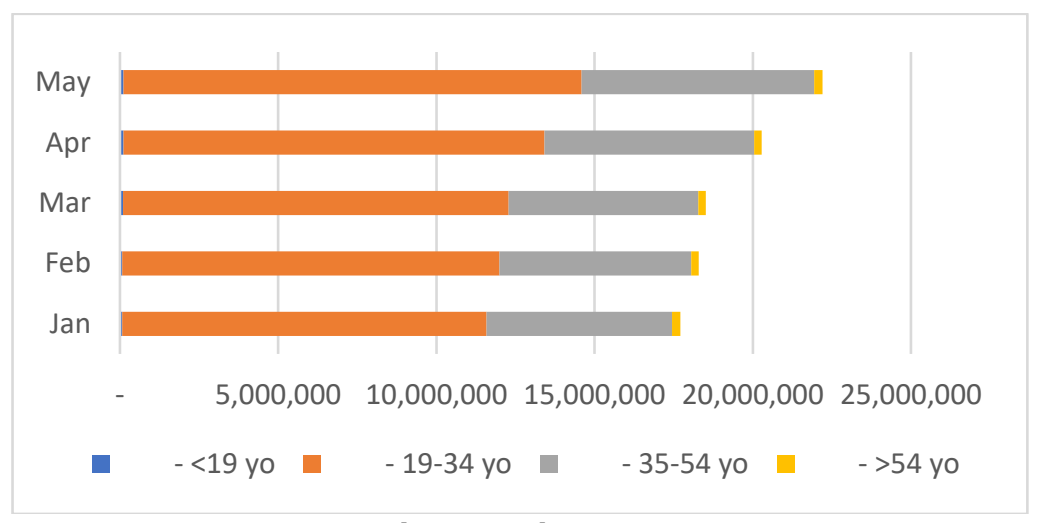

Figure 1. Total Entities by Age in 2021 Source: 0JK (2021)

Fintech lending is one of the most prominent fintech in the investing market right now. Besides that, some other investments that utilize fintech are crowdfunding, money market mutual funds, stock, digital gold, and so forth. Investment is a commitment to hold funds or assets for a certain period to obtain greater profits in the future (Jones \& Tuzel, 2013). The urgency in investing increases the value of wealth and welfare in the future and determines when a person can retire because they have attained financial independence (Jones \& Tuzel, 2013).

Simultaneous discussion of financial technology and investment leads to the next step where people have to consider and decide whether they will make some investment or not. Investment Decision is a complex way of thinking which influence by various factors. Based on Christanti and Mahastanti (2011), these investment decisions are inconsistent and unpredictable because it is all about assumptions that depend on how much information gain. Moreover, Christanti and Mahastanti (2011) also states two sides of personal investment decisions. The first one is based on optimizing economic welfare, and the second is investor behavior motivation based on the psychological aspect.

Furthermore, investor decisions depend on techniques, knowledge, expected cost, and risk perception (Harcourt et al., 1967). To make an excellent investment decision, investors need to dig and understand the whole concept of opportunity and risk to lower the financial loss. Economic theory (Virlics, 2013) explains that decision analysis has objective and subjective analysis, where counting the payoff and 
outcomes becomes the objective analysis, while the perspective of each investor becomes the subjective analysis. (Avram et al., 2009) also states that the decision-maker should make an investment evaluation based on the information received and the nature of the project to achieve the optimum appraisal value. All these factors will influence the final decision of whether the investor will invest or not.

As mention in previous studies, the investment decision is a subjective matter which could influence by many factors. Therefore, this research will only focus on three elements: financial literacy, motivation, and digitalization. Financial literacy is defined as knowledge, skills, and beliefs that influence a person's attitudes and behavior to improve decision-making and financial management to achieve prosperity (OJK, 2013). Although, according to 0JK (2020), in 2019, the financial literacy level in Indonesia showed only $38.03 \%$ nationally, while the rest of $61.97 \%$ were still categorized as insufficient literate.

Financial literacy has an essential role in these financial sectors, especially on investment. Minimum there are two impacts of financial literacy; first, it influences individuals' preference to manage their financial plans, and second, it will impact the financial sector in an enormous scope. People with adequate financial literacy will benefit from working on their financial projects, such as setting or allocating funds correctly (Robb \& Woodyard, 2011). (Huston, 2010) also states that financial literacy will lead people to decide on their financial revenue based on their knowledge and ability. Thus, in an enormous scope, financial literacy is one of the essential elements in increasing financial depth (Grohmann et al., 2018). Furthermore, based on economic behavior research in Russia, the low level of society's financial literacy can affect public participation in financial markets (Fedorova et al., 2015).

Another aspect predicted to determine millennials' investment decisions is motivation. Investment motivation defines as an action taken by an investor to achieve specific goals (William, 2005). Besides, psychological factors can influence a person to make decisions (Manurung, 2012) either in the financial market or individual financial plans (Arianti, 2018). These statements align with the theoretical approach of Nofsinger (2001), which defines psychological factors can influence financial behavior on investment and other financial activity. Concretely, Daskalakis and Yue (2017) describe the two most dominant motivations underlying young people investing in fintech lending and crowdfunding: high returns and interest or excitement.

The last factor predicted to influence the millennial investment decision is digitalization. Along with the development of the internet and technology, digitalization takes over the conventional process of investment. Every investment platform implements digitalization in every step to increase efficiency and optimize the investment process. The support of the internet and digitalization in investment products has proven to reduce cost, create a remarkable circumstance for traders (Walia \& Kumar, 2007), and give investment information access easily (Barber \& Odean, 2001a). Furthermore, digitalization opens wide the chance for small businesses to develop and conduct funding from different investors. On the other side, digitalization also giving more opportunities for the investor with an inadequate budget. Thus, digitalization in financial sectors has proven to help millennials find investment platforms that suit the characteristics of novice investors and help solve problems both before and after investing (Snow \& Rasso, 2017).

\section{Method}

This research adopted single-equation regression models to examine the dependent variable on several explanatory variables and estimate mean or average value. Data was collected using the primary data collection method to 140 students in Economic Development Department in Universitas Negeri Malang. In general, several tests are conducted to get the final result, including validity test, reliability test, structural model test, and hypothesis test. Data analysis uses four variables: one dependent variable, investment decision, and three independent variables: financial literacy, motivation, and digitalization. These variables are an improvement from previous research by Arianti (2018); Bebasari and Istikomah (2020); Solanki et al. (2019). The investment decision variable becomes the dependent variable to capture what influences millennials to invest their money. Question about are they into an investment, and their priority becomes the measurement of this indicator.

Motivation is the first independent variable uses to measure the reason behind why millennials investing their money. In this case, the motivation divides into financial and non-financial motives, such as the motive to receive more income, gain profit, or have a better life in the future. Financial literacy, the second independent variable, is projected to study how literate these millennials are. Nowadays, millennials have easy access and considerable opportunities to learn about financial literacy through various media such as class materials, discussions, social media, society. In this variable, we researched how millennials build strategies to manage financial plans. The last variable is digitalization, described as the development of financial technology that intermediates the entrepreneur with the investment manager and investors. 
Digitalization in this subject measures how far investment technology influences millennials' decision to invest. For example, an investment manager who develops their technology, The following is the model used in this study.

\section{Definition:}

$$
I D_{i}=\propto+\beta_{1} F L_{i}+\beta_{2} M_{i}+\beta_{3} D_{i}+e_{i}
$$

$\begin{array}{ll}\text { ID } & \text { : Investment decision } \\ \text { FL } & \text { : Financial Literacy } \\ \text { M } & \text { : Motivation } \\ \text { D } & \text { : Digitalization } \\ \text { e } & \text { : error term }\end{array}$

\section{Result and Discussion}

Before analyzing the model using multiple regression, the data will test using validity and reliability. First, validity testing aims to ensure if the data are valid and appropriate in measuring the research indicators. The validity testing result analyzes through the value of Pearson correlation which describes the relationship between each indicator and the total number of variables. The result is considered valid if the correlation value is more than 0.3 (Sujianto, 2009). Second, reliability testing sought to identify that the data is consistent and reliable to become research object measurement. Cronbach's Alpha value captured the result of the reliability test. When the Cronbach's Alpha value exceeds the $r$ table, the indicators are considered consistent and reliable measurements (Sujianto, 2009)

Pearson correlation values for financial literacy, motivation, and digitalization in order are $0.56,0.67$, 0.71 , which exceed 0.3. Refer to that value, and it concludes that all of the indicators are valid. The same result comes from the reliability test, which captures that each indicator used in this study is more than the r-table, which means that the indicator is proven consistent and reliable as variables measurement. After conducting initial testing using validity and reliability tests, the next step is to process data through multiple regression. Based on data processing using SPSS is provided in Table 1.

Table 1. Analysis Result

\begin{tabular}{llll}
\hline Variables & Coefficient & T -statistic & Probability \\
\hline C & 2.294 & 3.527 & 0.001 \\
Financial Literacy & 0.139 & 4.399 & 0.000 \\
Motivation & 0.107 & 2.205 & 0.029 \\
Digitalization & -0.39 & -0.858 & 0.392 \\
R-square & & & 0.376 \\
F-stat & & & 7.429 \\
Prob F - stat & & 0.000 & \\
\hline
\end{tabular}

Note: ${ }^{*}$ significant at $95 \%$

Based on Table 2, there is some critical highlight, such as coefficient, R-squared, t-stat, and f-stat. Tstat test or partial testing intended to determine the influence of each independent variable on the dependent variable. Based on the results, the p-value of variables financially duration, motivation, and digitalization in a row are $0.000,0.0029$, and 0.392 , respectively. These numbers show that only financial literacy and motivation have a small probability value of less than 0.05 . In opposite, the digitalization variable has a higher probability value which is more than 0.05 . The smaller the value, shows that the independent variable has a significant influence dependent variable. Thus, financial literacy and motivation variables substantially impact investment decisions, while digitalization does not. The next step is capturing the effect of all variables simultaneously through the F-test. Based on the result, the probability value of the F-test is 0.00 , which is less than the significance level of 0.05 . It means that financial literacy, motivation, and digitalization have a stimulant influence on millennial investment decisions.

The data analysis shows that the investment decision measurement using the three independent variables described above is not optimal. This conclusion obtains from the R-square value of 0.37 , far from the maximum value of $100 \%$. This value indicates that the independent variable explains only $37 \%$ of the variation in the dependent variable. In comparison, the remaining $63 \%$ influence by other variables not included in the study. In other words, numerous variables can influence millennials' investment decisions 
apart from financial literacy, motivation, and digitalization. Further research and exploration are needed to find out what variables significantly affect millennials' investment.

The equation below explains how far the constant represents each variable. Constanta of financial literacy is 0.139 shows that every improvement on Millenials' financial literacy will increase the number of investment decisions by 0.139 points. Positive affect is also represented by the influence of motivation, which every additional motivation increases the investment decision by 0.107 points. Different from the two other results, digitalization has a negative correlation, yet this correlation is not significant.

Nowadays, unlimited source about financial literacy is available to access through various ways. Moreover, internet development supports this endless information and positively impacts investment ((Solanki, Wadhwa, \& Gupta, 2019). Based on the data analysis, there is a significant correlation between financial literacy and investment decisions. This positive relation is in line with some research (Tarora \& Juwita, 2017) where financial literacy background in saving, loan, and investment will influence the investment decision. Millennials with huge financial literacy on investment can precisely analyze the risk and return, leading the decision on the best time to put their money on the investment. Bebasari \& Istikomah (2020) states that students with sound financial literacy have immense opportunities to minimize the risk and optimize the investment return.

On the other hand, this result contradicts the study by (Barber \& Odean, 2001a, 2001b), which indicates that investor financial literacy has no significant impact on investment decisions. Both of their result study shows that abundance information results in overconfidence in choosing the stock. In this case, the higher an investor's financial literacy can lead to overestimation and accuracy of a person in determining investment decisions. Nisa (2017) also states that investment knowledge from class or other media has no impact on student's interest to invest in the capital market.

This contradictive result is likely to happen because there is a shift in millennials' behavior at a particular time. It happens due to the ease of access to information. In the previous studies, technological developments were not as fast as today, and millennials' access to information is not as comprehensive as now. In addition, this difference also supports by the indicators used to estimate the financial literacy variable. These indicators contain questions about the risk profile's knowledge and understanding of investment risks and returns, which nowadays are easily obtained by Millenials from various social platforms such as Website, YouTube, Instagram, Tik Tok and so forth.

Motivation has a significant correlation with the investment decision. This result aligns with some research where motivation leads to increased investment decision. Nisa (2017) also support this result, showing that students' motivation influences the decision to invest in the capital market. Investment motivation is also ruled by opinions to meet future needs and prepare for a prosperous future However, this is inversely proportional to external motivation that underlies investment activities. External motivation is one of the elements considered in the millennial generation's investment achievement choices, including lifestyle, social environment, and financial management (Rosdiana, 2020). In terms of the social environment, the millennial generation tends to have a wasteful pattern of behavior. The priority scale shifts to following rising trends rather than allocating funds they have on post-investment (Azizah, 2020) to achieve motivation and realize investment choices and actions become slower.

Moreover, human motivation to invest in financial markets is to expect maximum profit with low risk (Markowitz, 1952) to achieve specific goals in the future. However, before planning the investment, the millennial generation has pretty complex considerations which divide into two different points of view. Internal motivation, such as psychological motivation, is influenced by four variables: positive attitude, familiarity, trust, and nationalism, which directly affect investment decisions (Zalviwan et al., 2020), while external factors include are lifestyle, suggestions in social media, and social environment. Thus, internal and external motivation must work together to align the investment motivation of the millennial generation to invest.

Based on data processing results, there is no significant effect between digitalization and the youth's decision to invest. Furthermore, this shows that no matter how sophisticated the application made by the investment platform will be, it will not affect the millennial's decision to invest. The results of this study support by research conducted by Snow \& Rasso (2017), where digital sophistication find in large investors who have high capital adequacy and have access to complete information. Sophistication is not seeing in small, uninformed investors. The support of the results of this study is suspected because the samples used in this study are millennials who have limited capital or small investors, so sophistication or digitization is not something that can have a significant influence on investment decisions.

Furthermore, the massive development of digitalization giving complete information to the investor through the internet. However, these significant sources of information tend to give disoriented details, which leads the decision to nowhere simply because investors couldn't proceed with all information ideally Mirsch et al., (2017). However, digitalization is not always an option in determining investment decisions. 
Digitalization is a tool to supports investment decisions for Millenials, specifically the presence of complete accessible information (Solanki et al., 2019). In the previous research about information and communication digitalization, the investor has different reactions facing capital market information. Investors tend to react confidently to publication information when the market is positive and react inversely when the market trend is negative (Han \& Hirshleifer, 2016). In line with Yang et al., (2017), a survey of social media and mass media on the decision to invest shows that investors tend to focus only on profitable reports and avoid the opposite when the market is on an upswing. Generally, investors' level of understanding or financial literacy remains a fundamental reason influencing investment decisions.

\section{Conclusion and Suggestion}

These study results indicate that the financial literacy variable has a significant effect on investment decisions. Financial literacy provides the foundation for taking action, which is in determining investment decisions. A higher understanding of financial literacy drives a greater penetration in financial investment, leading to the fulfillment of investment goals and increased investor welfare. Moreover, motivation has a positive correlation with investment decisions, while digitalization variables showed an insignificant effect. Therefore, internal and external motivation could be one of the variables considerations in making investment choices, especially for the millennial generation who have more comprehensive options to invest. Meanwhile, the digitalization variable has only become a supporting way to give the millennial generation an easier way to invest. Comprehensive information and easy access to investment facilities only support this process, but the main pivot factor is still the investment capital and understanding financial literacy.

\section{References}

Arianti, B. F. (2018). The influence of financial literacy, financial behavior and income on investment decision. EAJ (Economic and Accounting Journal), 1(1), 1-10.

Avram, E. L., Savu, L., Avram, C., IGNAT, A. B., Vancea, S., \& Horja, M. I. (2009). Investment decision and its appraisal. Annals of DAAAM \& Proceedings.

Azizah, N. S. (2020). Pengaruh literasi keuangan, gaya hidup pada perilaku keuangan pada generasi milenial. Prisma (Platform Riset Mahasiswa Akuntansi), 1(2), 92-101.

Barber, B. M., \& Odean, T. (2001a). Boys will be boys: Gender, overconfidence, and common stock investment. The Quarterly Journal of Economics, 116(1), 261-292.

Barber, B. M., \& Odean, T. (2001b). The internet and the investor. Journal of Economic Perspectives, 15(1), 41-54.

Bebasari, N., \& Istikomah, A. (2020). The effect of investment motivation, financial literation, and financial behavior on investment decisions (Studies on Management Students at Pelita Bangsa University). Journal of Research in Business, Economics, and Education, 2(4), 842-851. https://ojk.go.id

Bollaert, H., Lopez-de-Silanes, F., \& Schwienbacher, A. (2021). Fintech and access to finance. Journal of Corporate Finance, 68, 101941. https://doi.org/10.1016/j.jcorpfin.2021.101941

Christanti, N., \& Mahastanti, L. A. (2011). Factors considered by investors in investing. Journal of Theory and Applied Management, 4(3), 37-51.

Daskalakis, N., \& Yue, W. (2017). User's Perceptions of Motivations and Risks in Crowdfunding with Financial Returns. SSRN Electronic Journal. https://doi.org/10.2139/ssrn.2968912

Databoks. (2021). Jumlah pengunjung tokopedia kalahkan shopee pada kuartal I-2021. https://databoks.katadata.co.id/datapublish/2021/06/11/jumlah-pengunjung-tokopediakalahkan-shopee-pada-kuartal-i-2021

Fedorova, E. A., Nekhaenko, V., \& Dovzhenko, S. E. (2015). Impact of financial literacy of the population of the Russian federation on behavior on financial market. Empirical Evaluation. Russian Economic Develompment, 26(4), 394-402.

Grohmann, A., Klühs, T., \& Menkhoff, L. (2018). Does financial literacy improve financial inclusion? Cross country evidence. World Development, 111 84-96. https://doi.org/10.1016/J.WORLDDEV.2018.06.020

Gujarati, D. N. (2004). Basic econometrics. The Mc-Graw Hill.

Han, B., \& Hirshleifer, D. A. (2016). Social transmission bias and active investing. HKUST Finance Symposium. Harcourt. (1967). Economic Activity (Re-issued). Cambridge University Press, New York.

Huston, S. J. (2010). Measuring financial literacy. Journal of Consumer Affairs, 44(2), 296-316.

Jones, C. S., \& Tuzel, S. (2013). Inventory investment and the cost of capital. Journal of Financial Economics, $107(3), 557-579$ 
Lee, C. C., Li, X., Yu, C. H., \& Zhao, J. (2021). Does fintech innovation improve bank efficiency? Evidence from China's banking industry. International Review of Economics and Finance, 74, 468-483. https://doi.org/10.1016/j.iref.2021.03.009

Manurung, A. . (2012). Teori Investasi: Konsep Dan Empiris. PT Adler Manurung Press.

Markowitz, H. (1952). The utility of wealth. Journal of Political Economy, 60(2), 151-158.

Mirsch, T., Lehrer, C., \& Jung, R. (2017). Digital nudging: Altering user behavior in digital environments. Proceedings Der 13. Internationalen Tagung Wirtschaftsinformatik (WI 2017), 634-648.

Nisa, A. (2017). Pengaruh pemahaman investasi, modal minimal investasi dan motivasi terhadap minat mahasiswa berinvestasi di pasar modal (Studi pada Mahasiswa Sekolah Tinggi Kesuma Negara). Jurnal Penelitian Teori \& Terapan Akuntansi (PETA), 2(2), 22-35.

Nofsinger, J. R. (2002). Investment Blunders of the rich and famous-and what you can learn from them. FT Press.

OJK. (2013). National Strategy of Financial Literacy of Indonesia.

OJK. (2020). Survei Nasional Literasi dan Inklusi Keuangan 2019. https://www.ojk.go.id/id/berita-dankegiatan/publikasi/Pages/Survei-Nasional-Literasi-dan-Inklusi-Keuangan-2019.aspx

OJK. (2021). Statistik fintech lending periode Mei 2021. https://www.ojk.go.id/id/kanal/iknb/data-danstatistik/fintech/Pages/Statistik-Fintech-Lending-Periode-Mei-2021.aspx

Robb, C. A., \& Woodyard, A. S. (2011). Financial knowledge and best practice behavior. Journal of Financial Counseling and Planning, 22(1), 60-70.

Rosdiana, R. (2020). Analysis of Investment interests, motivation, social environment, financial literacy (Comparative study of generation $\mathrm{Z}$ and millennial generation). International Journal of Business, Economics and Law, 22(1), 111-121.

Snow, N. M., \& Rasso, J. (2017). If the tweet fits: How investors process financial information received via social media.

Solanki, S, Wadhwa, S, Gupta, S. (2019). Digital technology: An influential factor in investment decision making. International Journal of Engineering and Advanced Technology, 8(6S4), 27-31. https://doi.org/10.35940/ijeat.f1007.1186s419

Sujianto, A. E. (2009). Aplikasi statistik dengan SPSS 16.0. Jakarta: Prestasi Pustaka, 97.

Tarora, H., \& Juwita, R. (2017). Analisis Pengaruh Literasi Keuangan Terhadap Keputusan Investasi (Studi Kasus Nasabah Asuransi Generali Indonesia Cabang Palembang).

Virlics, A. (2013). Investment decision making and risk. Procedia Economics and Finance, 6, 169-177. https://doi.org/10.1016/s2212-5671(13)00129-9

Walia, N., \& Kumar, R. (2007). Online stock trading in India: An empirical investigation. Indian Journal of Marketing, 37(4).

William, F. (2005). Investasi (1st ed.). PT. Indeks Kelompok Gramedia.

Yang, W., Lin, D., \& Yi, Z. (2017). Impacts of the mass media effect on investor sentiment. Finance Research Letters, 22, 1-4.

Zalviwan, M., Haryono, T., \& Sawitri, H. S. R. (2020). Investors psychology on the biased investment decision: The mediating effect of extra-motivation to invest. Jurnal Keuangan Dan Perbankan, 24(4), 506-519. 